\title{
An ecological water-based drilling mud (WBM) with low cost: substitution of polymers by wood wastes
}

\author{
Soumia Haider ${ }^{1} \cdot$ Mohamed-Zine Messaoud-Boureghda $^{2} \cdot$ Hamid Aknouche $^{1} \cdot$ Ali Akkouche $^{1} \cdot$ Larbi Hammadi $^{3}$. \\ Brahim Safi ${ }^{1}$ (D)
}

Received: 7 December 2017 / Accepted: 4 April 2018 / Published online: 24 April 2018

(c) The Author(s) 2018

\begin{abstract}
An ecologically friendly water-based drilling mud (WBM) was designed by using wood wastes (WP: wood powder) in order to substitute the organic polymers which are very expensive and often make the higher cost of the oil well drilling. This present work is dedicated on studying the rheological behavior and main rheological properties of WBM containing the wood powder at different contents and sizes by substitution of usually used polymers. The effect of wood powder on the drilling fluid filtrate was also analyzed. The drilling fluid that was developed has better rheological properties and fluid loss control which are required for a good functioning of oil well drilling. By a total substitution of polymers, the wood powder $\left(300 \mu \mathrm{m}\right.$ at $\left.850 \mathrm{~kg} / \mathrm{m}^{3}\right)$ can be used as a filtrate reducer of mud because the WBM filtrate obtained exhibits a minimum and having requested values for such formation.
\end{abstract}

Keywords Wood wastes $\cdot$ Drilling mud $\cdot$ Organic polymer $\cdot$ Yield point $\cdot$ Viscosity $\cdot$ Rheological behavior

\section{Introduction}

The use of polymers such as cellulose derivatives (Bentriou et al. 2014; Yang et al. 2007; Kok and Alikaya 2005; Leliang and Guijuan 2003; Ling et al. 1999; Hughes et al. 1993), biopolymers (Jun et al. 2001; Xie et Lecourtier 1992; Navarrete et al. 2001), and guar gum (Bentriou et al. 2014; Mahto and Sharma 2004; Sharma et Mahto 2006) became indispensable in water-based drilling fluids to replace the oil-based mud for environmental considerations. Many studies were carried using different polymers in formulation of water-based drilling muds. These studies have shown the efficiencies of some polymers on the rheological and physicochemical performance of fluid. Comparing between the different polymers, the most used principally as a filtrate

Brahim Safi

safi_b73@univ-boumerdes.dz

1 Research Unit: Materials, Processes and Environment (RU/MPE), University M'Hamed Bougara of Boumerdes, Boumerdes, Algeria

2 Research Laboratory of Food Technology, University M'Hamed Bougara of Boumerdes, Boumerdes, Algeria

3 University of Sciences and Technology of Oran. Mohamed Boudiaf (USTO-MB), Oran, Algeria reducer is the cellulose derivative because it is biodegradable and compatible with other components of drilling mud. Carboxy-methyl-cellulose (CMC) is produced by cellulose reaction obtained from wood pulp or cotton fiber with chloroacetic acid and $\mathrm{NaOH}$. Among the polymers most used as a fluid loss reducer of WBM is that of polyanionic cellulose (PAC) because it has the power to increase the viscosity of the suspension. The latter is also regarded as viscosity modifier of the mud system (Safi et al. 2016; Bruton et al. 2000). Two types of polymer PAC are available: the high viscosity and the low viscosity. Both of them have the same degree of fluid loss control, but different degrees of viscosity (Safi et al. 2016; Baba Hamed and Belhadri 2009; Plank 1992).

However, research tends to use or valorize some wastes to minimize the cost of drilling operation. Today, environmental constraints require us to seek an alternative component for drilling fluids that can replace the polymers without disrupting rheological characteristics of drilling fluids. Among wastes that can be used as component of drilling fluids is that the wood wastes. According to the literature review, it is noted that no studies have been performed on the use of wood powder or wood dust in formulation of drilling fluids. The wood sawdust designates all wood waste obtained from the lumber and produced during machining operations performed on the raw material (wood). The resulting chips of 
manufacture can be well recovered and recycled to the field of construction (Kim and Song 2014; Kim et al. 2013; Jungmeier et al. 2003). Many researches have been conducted using wood sawdust in different fields and different forms (Daoui et al. 2015; Djoudi et al. 2012; Briens et al. 2008; Turgut and Algin 2007; Garrote et al. 2003). However, few study research has been conducted using wood wastes as a filtration control and density additives in WBM (Adebayo and Precious 2012; Anawe Paul et al. 2015). In this work, the authors found that an optimum weight percentage of sawdust was obtained, and it is recommended for application of the different size grades of the sawdust if they are to serve as weight control additive. The contents founds are $5.9 \mathrm{wt} \%$ sawdust for $0.5 \mathrm{~mm}, 3.8 \mathrm{wt} \%$ sawdust for $1.0 \mathrm{~mm}$, and $3.5 \mathrm{wt} \%$ for greater than $1.0 \mathrm{~mm}$ sawdust. The authors were observed also that for weight percentage higher than $5 \%$ for sawdust greater than $1.0 \mathrm{~mm}$, the mud cake was very unstable. The reuse of different wood wastes was also the subject of numerous studies but in another material not drilling fluids (Daoui et al. 2015; Djoudi et al. 2012). The structural properties of wood and the presence of longitudinal cavity are of interest in the treatment of wastewater, by fixing various undesirable elements on the walls of the material. Sawdust, natural or chemically treated, from different tree species, has been the subject of several studies on their ability to fix different pollutants in wastewater. However, recovery and usage of sawdust or wood powder as constituent in the drilling fluids need to be studied. For this, our study will focus on the use and recycling of wood powder by polymer substitution in WBM.

\section{Experimental study}

\section{Materials used}

To conduct this study, the chosen water-based muds are those currently used for drilling oil wells in Algeria. Polymer products and materials used are bentonite, caustic soda, soda ash, potassium chloride, cellulose polyanionic (PAC_ul and PAC_R), carboxy-methyl-cellulose (CMC), and xanthane (XCD). Table 1 gives the composition and rheological properties of water-based mud used in this work. Those muds were prepared using API equipment (API RP 13B-1, 2003).

\section{Using the wood powder}

In order to evaluate the use of wood powder in WBM, the Aleppo pine wood was used in this work at three different fractions and dosages. The coupons of Aleppo pine were recovered as waste from wood manufacture. The wood powder was introduced by substitution, first of PAC_ul and
Table 1 Mud formulation for a density $d=1.05$

\begin{tabular}{lllll}
\hline Products & $\begin{array}{l}\text { Dosage } \\
\left(\mathrm{kg} / \mathrm{m}^{3}\right)\end{array}$ & Rheological properties & \\
\hline Caustic soda & 1 & Read speed & & PV cps \\
Soda ash & 0.7 & 600 & 54 & 16 \\
Bentonite & 20 & 300 & 38 & $\mathrm{AV} \mathrm{cps}$ \\
PAC-ul & 5.7 & 200 & 33 & 27 \\
PAC-R & 0.7 & 100 & 28 & Yvlbs $/ 100 \mathrm{ft}^{2}$ \\
CMC LV & 6 & 6 & 22 & 22 \\
XCD & 0.7 & 3 & 20 & \\
KCL & 40 & Gels $10^{\prime \prime} / 10^{\prime}$ & $21 / 25$ & \\
Defoamer & 0.5 & Filtrate cc/30 mn & & 6 \\
\hline
\end{tabular}

$P V$ plastic viscosity; $A V$ apparent viscosity; and $Y v$ yield value or yield point

CMC, then secondly by substitution the XCD and PAC_R. This procedure was chosen to know the role played by the waste.

The microscopic structure of Aleppo pine used in this study, obtained by scanning electron microscopy (SEM) and $\mathrm{X}$-ray diffraction (XRD), is given in Fig. 1. According to the figure, this wood powder has a crystalline phase and an amorphous phase. It is noted that many studies have confirmed the structure of wood of Aleppo pine, because this wood type is composed of cellulose, hemi cellulose, lignin, and some trace minerals (Popescu and Vasile 2010; Popescu et al. 2011; Sugiyama et al. 1991). These minerals are generally in the silica cristobalite form (see Fig. 1a).

\section{Test methods}

Rheological behavior and parameters were determined by rheological tests. The rheological tests were conducted using a rheometer fann 35 at variable speed (3-600 rpm). A viscometer giving values in $\mathrm{cP}$ or in $\mathrm{mPa}$ s by using the formulas known from API recommended practice for field testing drilling fluids, and they are equations usually used on the site and also used by many authors (Safi et al. 2016; Bruton et al. 2000). API filtrate and gel 0/10 (3 rpm dial reading after mixing and after $10 \mathrm{~min}$ ) are determined with using API recommendations (API RP 13B-1, 2003).

\section{Results and discussions}

\section{PAC and CMC substitution by wood powder}

\section{Rheological behavior}

Figures 2, 3, 4, 5 give rheological behavior of studied WBMs with PAC and CMC substitution by WP at different contents 

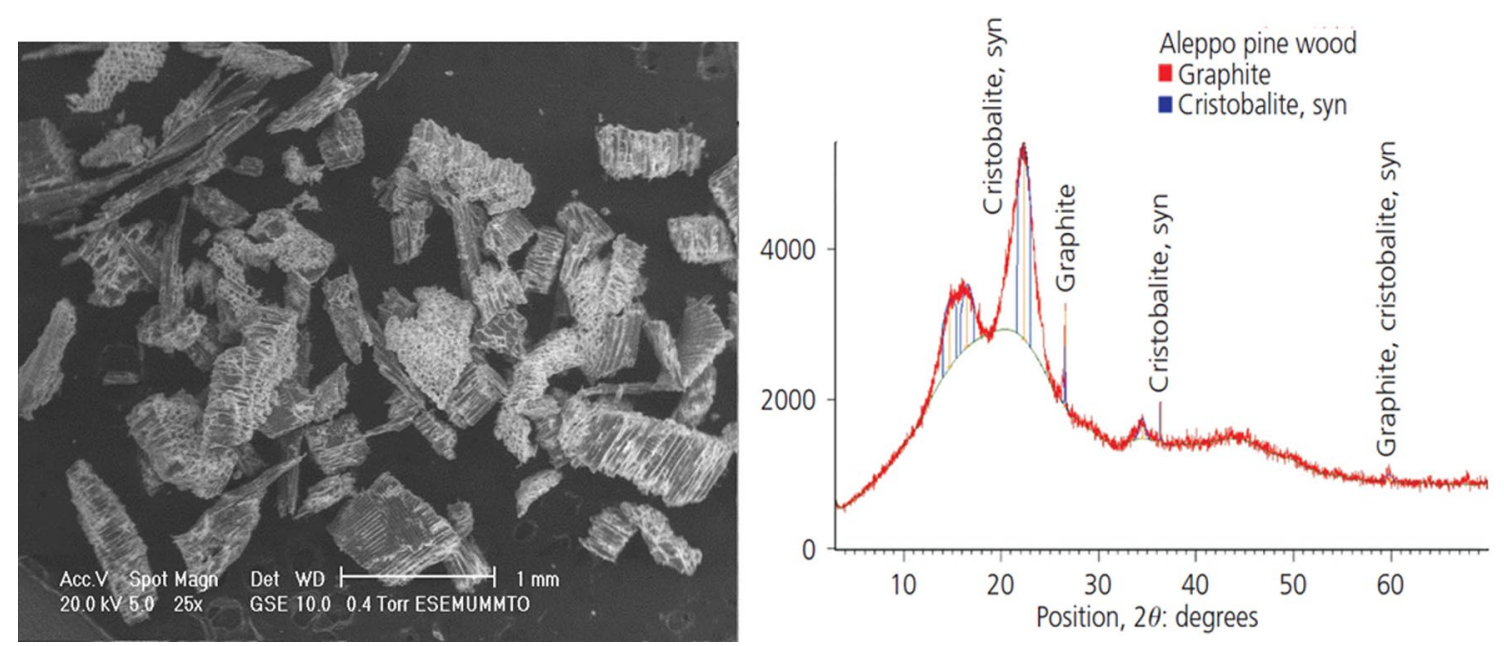

Fig. 1 Wood powder used (wastes of Aleppo pine). a SEM, b XRD

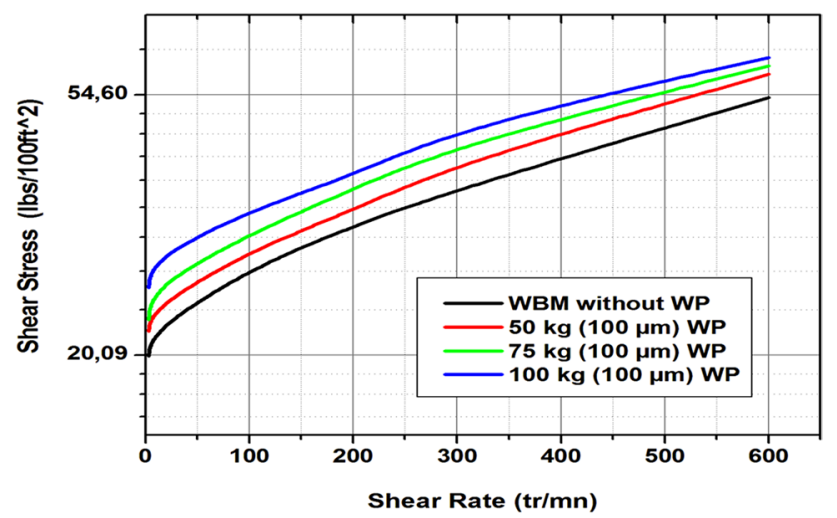

Fig. 2 PAC_ul and CMC substituted by wood powder (WP at size $=100 \mu \mathrm{m})$ at different contents

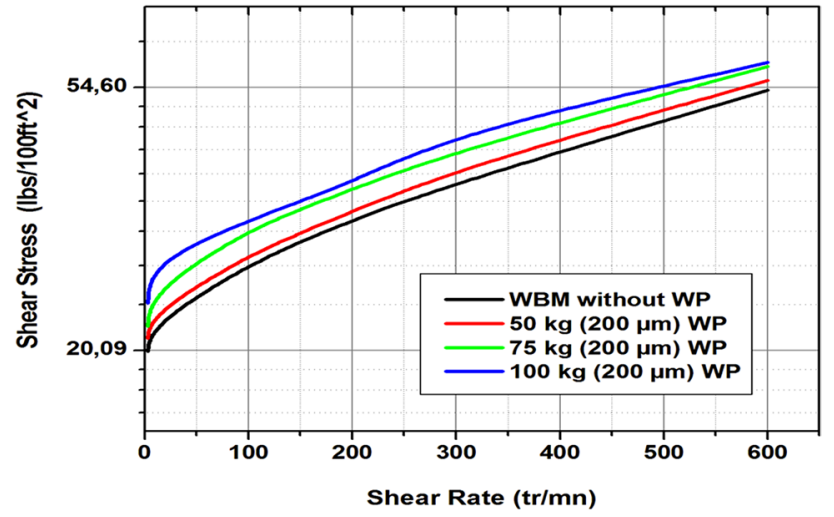

Fig. 3 PAC_ul and CMC substituted by wood powder (WP at size $=200 \mu \mathrm{m})$ at different contents

and particle sizes. According to obtained rheograms, all suspensions show non-Newtonian flow. However, the behavior of these suspensions can be identified by using rheological

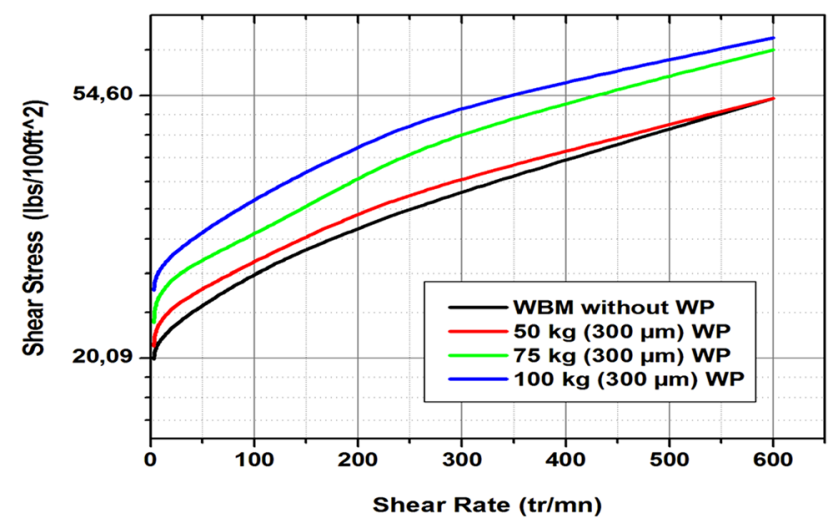

Fig. 4 PAC_ul and CMC substituted by wood powder (WP at size $=300 \mu \mathrm{m})$ at different contents

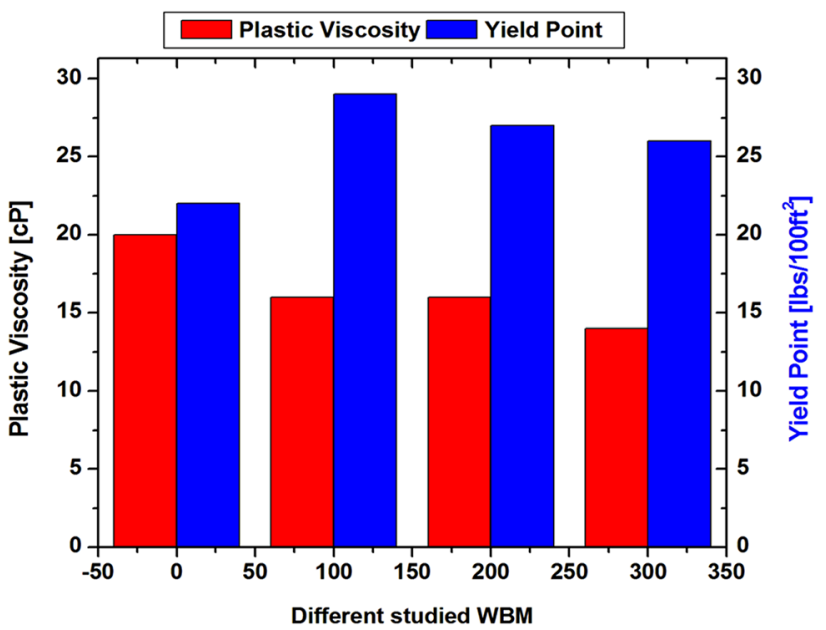

Fig. 5 Main rheological parameters of studied muds: PAC_ul and CMC substitution 
models known. Indeed, several studies have found that the behavior of these mud types follows the Herschel-Bulkely model. In this case, all studied muds show a non-Newtonian flow because the suspensions represent a flow threshold that means they have a non-Newtonian behavior. According to several researchers (Safi et al. 2016; Maallem et al. 2013; Kayacier and dogan, 2006), they have found that the behavior of these types of mud follows the model of Herschel-Bulkely. Regardless of the dosage and size of wood particles, rheological behavior of studied WBM is same and has Herschel-Bulkely behavior.

Generally, shear stresses for all the samples tend to increase as WP content increased. Also, effect of WP additive produced the decrease in viscosity at $100 \mathrm{~kg} / \mathrm{L}$. It was noted that with substitution of PAC and CMC per $100 \mathrm{~kg} / \mathrm{L}$ of PW, the viscosity increased by $29 \%$ and then stabilized above 200 and $300 \mathrm{~kg} / \mathrm{L}$. However, it is noted that yield value has fallen beyond these dosages. This proves that the wood powder has a viscosifying effect and can be used by replacing the viscosifier polymers.

\section{XCD and PAC_R substitution by wood powder}

\section{Rheological behavior}

Rheological behavior of WBMs with XCD and PAC_R substituted by WP at different contents and particle sizes is given in Figs. 6, 7, 8, 9. As the last results and according to

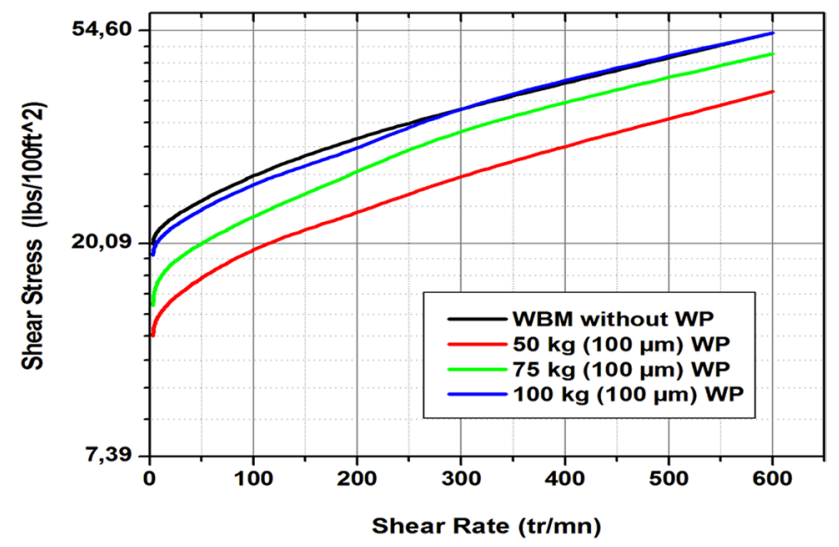

Fig. 6 XCD and PAC_R substituted by wood powder (WP at size $=100 \mu \mathrm{m})$ at different contents

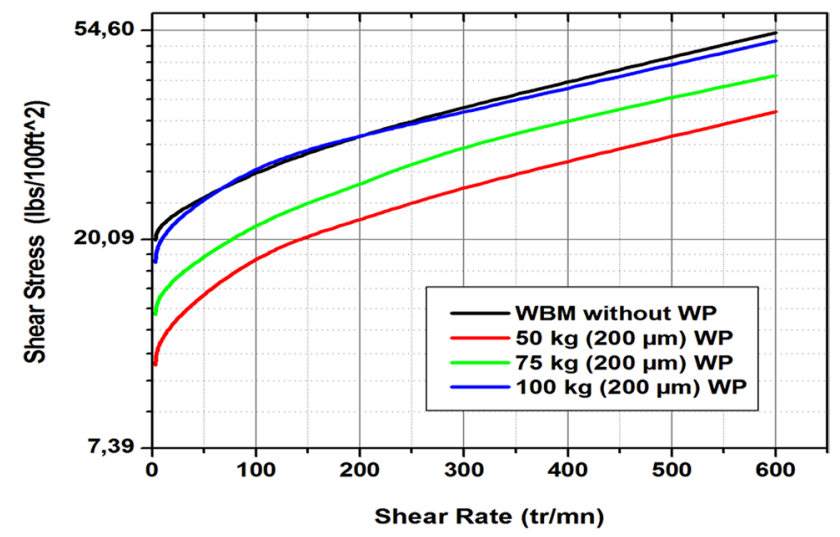

Fig. $7 \mathrm{XCD}$ and PAC_R substituted by wood powder (WP at size $=200 \mu \mathrm{m})$ at different contents

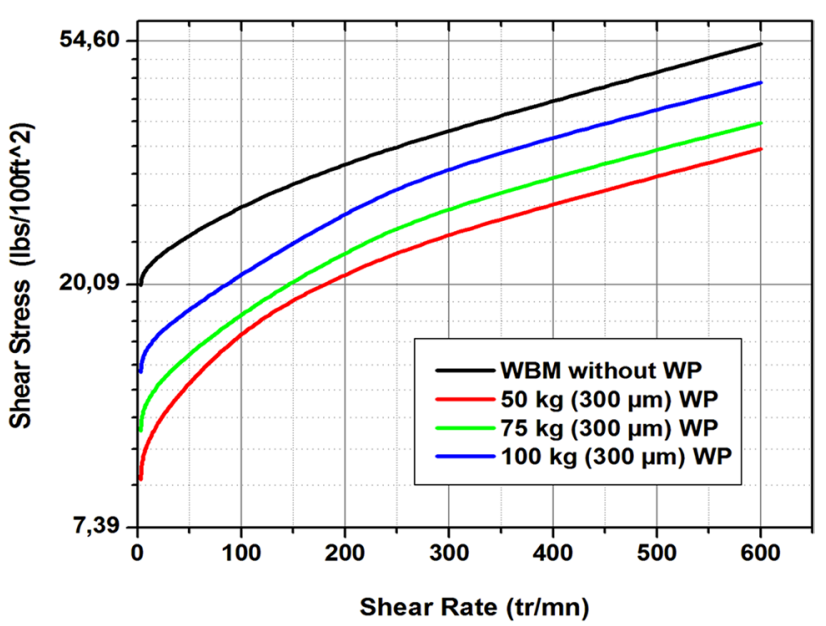

Fig. 8 XCD and PAC_R substituted by wood powder (WP at size $=300 \mu \mathrm{m})$ at different contents

obtained rheograms, all suspensions show non-Newtonian flow, and the behavior of these suspensions can be identified by using rheological models known. Same observations concerning the rheological behavior have been reported. However, the muds show also a non-Newtonian flow described by the Herschel-Bulkely model but with an other yield value (Safi et al. 2016; Maallem et al. 2013).

It can be seen that the shear stress increases with the increase in the WP content in all samples for different sizes; 


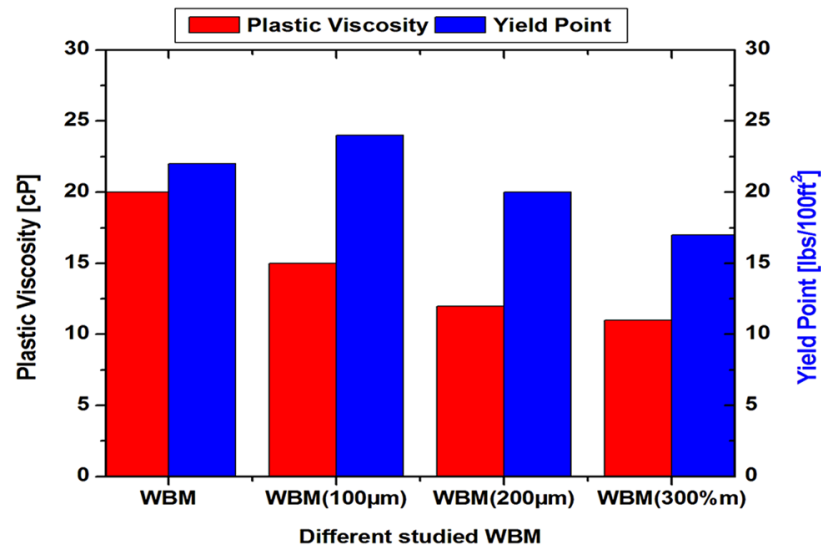

Fig. 9 Main rheological parameters of studied muds: XCD and PAC_R substitution

for that at 100 and $200 \mu \mathrm{m}$, it is superimposed on that without WP, and for that at $300 \mu \mathrm{m}$, it is much lower than that without WP. Meanwhile, the addition of the WP causes a decrease in plastic viscosity and that apparent such as the particle size of the WP increase, the decrease in plastic viscosity is greater for particles which have a size of $100 \mu \mathrm{m}$ and it stabilizes at sizes of 200 and $300 \mu \mathrm{m}$. The apparent viscosity is constant around $20 \mathrm{cP}$ for particles which have sizes from 0 to $100 \mu \mathrm{m}$ and decreases considerably for sizes of 200 to $300 \mu \mathrm{m}$. We can note also that the value of the yield increases for an addition of the WP which has sizes of $100 \mu \mathrm{m}$ and then it decreases for larger sizes.

The quantity of filtrate containing WBM samples where XCD and PAC-R were substituted by WP which has size of $100 \mu \mathrm{m}$ decreases according to the quantity of WP added, from $6 \mathrm{cc} / 30 \mathrm{mn}$ for a WBM without WP up to $3 \mathrm{cc} / 30 \mathrm{~min}$ for a WBM which has $100 \mathrm{~kg} / \mathrm{mm}^{3}$ of WP, while the filtrate quantity for WBM samples where PAC-ul and CMC were substituted by WP for same particle size $(100 \mu \mathrm{m})$ was reduced from 17 to $5 \mathrm{cc} / 30 \mathrm{mn}$. Compared to muds where XCD and PAC-R have been substituted by WP for the same size, mud filtrate has decreased as function as the quantity of WP added from $18 \mathrm{cc}$ for WBM samples which contain $50 \mathrm{~kg} / \mathrm{mm}^{3}$ to $5 \mathrm{cc} / 30 \mathrm{mn}$ for the WBMs containing $100 \mathrm{~kg} /$ $\mathrm{mm}^{3}$ (Fig. 10).

By comparing, the filtrate quantity obtained for different sizes of WP is found that for the substitution of XCD and PAC-R by WP, it is the same for all sizes, whereas for the
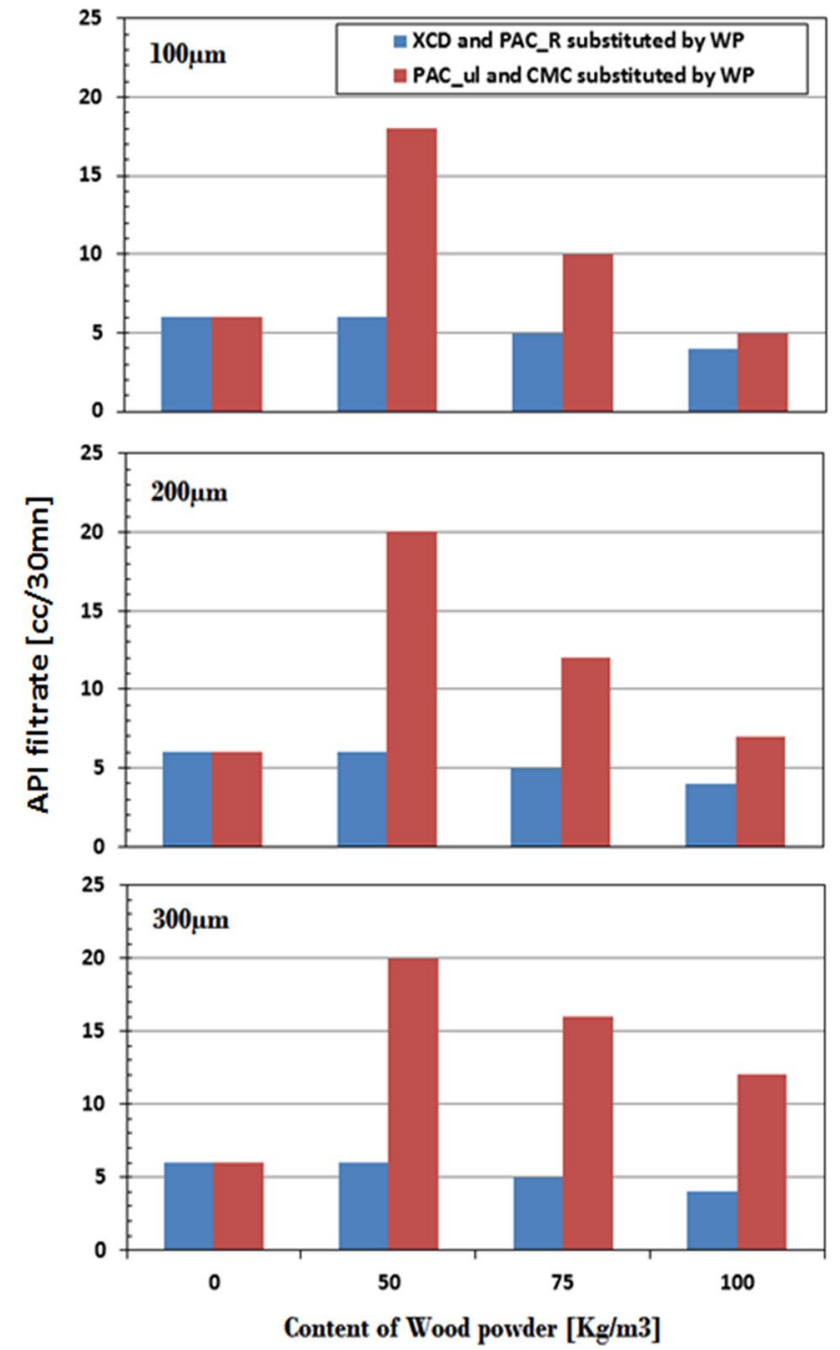

Fig. 10 Mud filtrate of studied muds at different polymer substitution and wood sizes

substitution of PAC-ul and CMC by WP, it is minimal for the sizes of $100 \mu \mathrm{m}$ and increases with increase in sizes of WP.

As an example to compared the cost price of a WBM containing WP (by $100 \%$ substitution of all polymers used) with that currently used mud for drilling oil wells in Algeria. Table 2 summarizes the comparison between a WBM containing imported polymers and that made from wood coupons. This table gives the main characteristics of WBM 
Table 2 Rheological characteristics, API filtrate, and cost price of water-based muds

\begin{tabular}{|c|c|c|c|c|c|c|c|}
\hline & \multirow[t]{2}{*}{ Products } & \multirow[t]{2}{*}{ Dosage $\left(\mathrm{kg} / \mathrm{m}^{3}\right)$} & \multicolumn{4}{|c|}{ Rheological characteristics and API filtrate } & \multirow[t]{2}{*}{ Cost price $/ \mathrm{m}^{3}$} \\
\hline & & & $\begin{array}{l}\text { Apparent vis- } \\
\text { cosity }(\mathrm{cP})\end{array}$ & $\begin{array}{l}\text { Plastic viscos- } \\
\text { ity }(\mathrm{cP})\end{array}$ & Yv $\left(\mathrm{lbs} / 100 \mathrm{ft}^{2}\right)$ & $\begin{array}{l}\text { API filtration } \\
(\mathrm{cc} / 30 \mathrm{mn})\end{array}$ & \\
\hline \multirow{8}{*}{$\begin{array}{l}\text { WBM with } \\
\text { wood powder }\end{array}$} & Caustic soda & 1 & 10 & 35 & 30 & 8 & $<10 \$$ \\
\hline & Soda ash & 1 & & & & & \\
\hline & Bentonite & 80 & & & & & \\
\hline & Wood $300 \mu \mathrm{m}$ & 850 & & & & & \\
\hline & - & & & & & & \\
\hline & - & & & & & & \\
\hline & - & & & & & & \\
\hline & - & & & & & & \\
\hline \multirow[t]{9}{*}{ WBM } & Caustic soda & 1 & 16 & 27 & 22 & 6 & $>50 \$$ \\
\hline & Soda ash & 0,7 & & & & & \\
\hline & Bentonite & 20 & & & & & \\
\hline & PAC-ul & 5,7 & & & & & \\
\hline & PAC-R & 0 & & & & & \\
\hline & CMC LV & 6 & & & & & \\
\hline & $\mathrm{XCD}$ & 0 & & & & & \\
\hline & KCL & 40 & & & & & \\
\hline & Defoamer & 0,5 & & & & & \\
\hline
\end{tabular}

and the cost price. It is noted clearly that the wood wastes can be used at least as viscosifier agent or filtrate agent for drilling mud without disturbing the main rheological properties of mud.

\section{Conclusion}

In the present work, rheological and physic measurements have been used to characterize WBM was designed by using wood wastes in order to substitute the organic polymers which are very expensive and often make the higher cost of the oil well drilling. It can be concluded from obtaining results that WBM with WP has better rheological properties and fluid loss control which are required for drilling. It was founded that by a total substitution of polymers, the WP can be used $\left(300 \mu \mathrm{m}\right.$ at $\left.850 \mathrm{~kg} / \mathrm{mm}^{3}\right)$ as a filtrate reducer of mud because the WBM filtrate obtained exhibits a minimum and having requested values for such formation. According to the comparison of the cost price of a WBM containing wood wastes (by $100 \%$ substitution of all polymers used) with that currently used for drilling oil wells in Algeria, it appears that the wood wastes can be used at least as viscosifier agent or filtrate agent for drilling mud without disturbing the main rheological properties of mud.
Open Access This article is distributed under the terms of the Creative Commons Attribution 4.0 International License (http://creativeco mmons.org/licenses/by/4.0/), which permits unrestricted use, distribution, and reproduction in any medium, provided you give appropriate credit to the original author(s) and the source, provide a link to the Creative Commons license, and indicate if changes were made.

\section{References}

Adebayo TA, Chinonyere PC (2012) Sawdust as a filteration control and density additives in water-based drilling mud. Int J Sci Eng Res 3(7):1-2

Anawe Paul AL, Efeovbokhan Vincent E, Adebayo Thomas A, Nwaogwugwu MM (2015) The effect of rice husk and sawdust on the properties of oil-based mud at varied temperatures. J Mater Environ Sci 6(3):765-772

Baba Hamed S, Belhadri M (2009) Rheological properties of biopolymers drilling fluids. J Pet SciEng 67:84-90

Bentriou A, Fourar K, Benmounah A, Safi B (2014) Comparative study of biopolymers action on physico-chemical and rheological properties of water-based drilling muds. Asian J Chem 26(14):4386-4390

Briens C, Piskorz J, Berruti F (2008) Biomass valorization for fuel and chemicals production: a review. Int J Chem React Eng. https://doi. org/10.2202/1542-6580.1674

Bruton J, Mercer R, Paul D (2000) The application of new generation $\mathrm{CaCl} 2$ mud systems in the deepwater Gulf of Mexico. In: IADC/SPE drilling conference, New Orleans, February. SPE 59051 
Daoui A, Safi B, Rezak M, Zerizer A (2015) Use of wood waste (Aleppo pine) as a superplasticiser in self-compacting mortars. J Adv Cement Res, Thomas Telford Ltd 27(8):457-463

Djoudi A, Khenfer MM, Bali A, Kadri EH, Debicki G (2012) Performance of date palm fibers reinforced plaster concrete. Int J Phys Sci 7(21):2845-2853

Garrote G, Cruz J, Domínguez H, Parajó J (2003) Valorisation of waste fractions from autohydrolysis of selected lignocellulosic materials. J Chem Technol Biotechnol 78:392-398. https://doi.org/10.1002/ jetb. 760

Hughes TL, Jones TGJ, Houwen O (1993) Chemica characterization of CMC and its relationship to drilling-mud rheology and fluid loss. SPE Drill Complet 8:157-164

Jun S, Qianding L, Qian X (2001) A preliminary study on alkyl polyglucosides as biodegradable surface-active oilfield chemicals. Oilfield Chem 18(2):97-100

Jungmeier G, McDarby F, Evald A, Hohenthal C, Petersen AK (2003) Energy aspects in LCA of forest products. Int J Life Cycle Assess 8(2):99-105

Kayacier A, Dogan M (2006) Rheological properties of some gumssalemixed solutions. J Food Eng 72:261-265

Kim MH, Song HB (2014) Analysis of the global warming potential for wood waste recycling systems. J Clean Prod 69:199-207

Kim MH, Song HB, Song Y, Jeong IT, Kim JW (2013) Evaluation of food wastedisposal options in terms of global warming and energy recovery: Korea. Int. J. Energy Environ. Eng. 4:1

Kok MV, Alikaya T (2005) Effect of polymers on the rheological properties of KCl/Polymer type drilling fluid. Energy Source Part A 27:405-415

Leliang C, Guijuan W (2003) An overview of format base drilling and completion fluids system. Drill Fluid Complet Fluid 20(1):31-36

Ling L, Jinping G, Dongrong G (1999) An introduction to methyl glucoside drilling fluid system. Pet Drill Tech 27(1):49-51

Maallem M, Safi B, Saidi M, Benmounah A, Aboutaleb D (2013) Effect of alkalinity and the nature of the basic solution $\left[\mathrm{Ca}(\mathrm{OH})_{2}\right.$ and $\mathrm{Ba}(\mathrm{OH})_{2}$ ] on the zeta potential and rheological properties of the drilling mud. Asian J Chem 25(16):8848-8885
Mahto V, Sharma V (2004) Rheological study of a water based oil well drilling fluid. J Pet Sci Eng 45(1):123-128

Navarrete RC, Seheult JM, Coffey MD (2001) New biopolymers for drilling, drill-in, completions, spacer, and coil-tubing fluids, Part II. SPE Int Symp Oilfield Chem. Houston, Texas, pp 1-15

Plank JP (1992) Water based muds using synthetic polymers developed for high temperature drilling. Oil Gas J 90(5):40-45

Popescu MC, Vasile C (2010) Structural changes in biodegradable lime wood. Carbohydr Polym 79:362-372

Popescu MC, Popescu CM, Lisa G, Sakata Y (2011) Evaluation of morphological and chemical aspects of different wood species by spectroscopy and thermal methods. J Mol Struct 988:65-72

Safi B, Zarouri S, Chabane-Chaouache R, Saidi M, Benmounah A (2016) Physico-chemical and rheological characterization of waterbased mud in the presence of polymers. J Pet Explor Prod Technol 6(2):185-190

Sharma VP, Mahto V (2006) Studies on less expansive environmentally safe polymers for development of water based drilling fluids. In: SPE Asia pacific oil and gas conference and exhibition, Adelaide, Australia, p. 4

Sugiyama J, Persson J, Chanzy H (1991) Combined infrared and electron diffraction study of the polymorphism of native celluloses. Macromol J 24(9):2461-2466

Turgut P, Algin HM (2007) Limestone dust and wood sawdust as brick material. Build Environ 42:3399-3403

Xie W, Lecourtier J (1992) Xanthan behaviour in water-based drilling fluids. Polym Degrad Stabil 38:155-164

Yang XH, Zhu WL (2007) Viscosity properties of sodium carboxymethylcellulose solutions. Cellulose 14:409-417

Publisher's Note Springer Nature remains neutral with regard to jurisdictional claims in published maps and institutional affiliations. 